\title{
Nye retningslinjer for angina pectoris
}

\author{
Nylig er det publisert nye europeiske retningslinjer for diagnostisering og behandling av stabil koronar- \\ sykdom. Der anbefales et nytt flytdiagram for utredning ved mistanke om stabil angina pectoris.
}

Stabil angina pectoris er en relativt godartet tilstand, med en årlig forekomst av hjertedød på 0,6-1,4\% (1). Utredningen ved mistenkt stabil angina pectoris har tidligere vært relativt standardisert, med arbeidsEKG som første skritt.

I de nye europeiske retningslinjene, som nylig er publisert i European Hearth Journal, blir det beskrevet tre stadier i utredning av mistenkt stabil angina pectoris. Prosessen begynner med en klinisk evaluering av sannsynligheten for at pasienten har tilstanden (trinn 1) (ramme 1) (1). Sannsynlighetsgraden vurderes ut fra symptomer, alder og kjønn (tab 1) (2). Deretter etableres en diagnose ved hjelp av ikke-invasive tester (trinn 2). Dersom pasienten får diagnosen angina pectoris, startes optimal medisinsk behandling. For å avgjøre hvilke pasienter som bør undersøkes invasivt med angiografi og revaskularisering (trinn 3), anbefales det å gjøre en kalkulert risikostratifisering for den aktuelle pasienten.

Ved alvorlige symptomer bør tidlig invasiv koronar angiografi utføres uten forsinkelse. Trinn 2 og trinn 3 utelates. Ved signifikant stenose anbefales revaskularisering. Ved tvil om hvorvidt en stenose er signifikant eller ikke, anbefales det å gjøre trykkmålinger (Fractional Flow Reserve, FFR). Resultatet av målingen bestemmer hvorvidt det bør gjøres revaskularisering Ved en FFR-verdi > 0,80 skal det ikke gjøres revaskularisering. En FFR-verdi på 0,80 betyr at det er et blodtrykksfall på $20 \%$ over stenosen det måles ved. Videre anbefales det å utføre transtorakal ekkokardiografi hos pasienter med symptomer på stabil angina pectoris, for å utelukke alternative forklaringer på smertene.

Koronar CT-angiografi kan ifølge de nye retningslinjene betraktes som et alternativ til arbeids-EKG, spesielt hos symptomatiske pasienter som har lav til middels pretestsannsynlighet for å ha angina pectoris. Metoden har høy negativ prediktiv verdi, noe som kan skape trygghet i utvalgte tilfeller. Koronar CT -angiografi bør ikke gjøres hos pasienter der det er høy sannsynlighet for forkalkninger. Undersøkelsen

Tabell 1 Klinisk pretestsannsynlighet for stabil angina pectoris hos pasienter medbrystsmerter (2)

\begin{tabular}{|l|c|c|c|c|c|c|}
\hline & \multicolumn{2}{|c|}{ Typisk angina } & \multicolumn{2}{c|}{ Atypisk angina } & \multicolumn{2}{c|}{$\begin{array}{c}\text { Ikke-anginøse } \\
\text { brystsmerter }\end{array}$} \\
\hline Alder (år) & Mann (\%) & Kvinne (\%) & Mann (\%) & Kvinne (\%) & Mann (\%) & Kvinne (\%) \\
\hline $30-39$ & 59 & 28 & 29 & 10 & 18 & 5 \\
\hline $40-49$ & 69 & 37 & 38 & 14 & 25 & 8 \\
\hline $50-59$ & 77 & 47 & 49 & 20 & 34 & 12 \\
\hline $60-69$ & 84 & 58 & 59 & 28 & 44 & 17 \\
\hline $70-79$ & 89 & 68 & 69 & 37 & 54 & 24 \\
\hline$\geq 80$ & 93 & 77 & 78 & 47 & 65 & 32 \\
\hline
\end{tabular}

\section{$\square$ Ingen ytterligere undersøkelser}

$\square$ Undersøkelse med arbeids-EKG. Andre, ikke-invasive bildediagnostiske metoder kan velges

$\square$ Ikke-invasiv, funksjonell bildediagnostikk

$\square$ Det kan antas at pasienten har stabil angina pectoris og det bør utføres risikostratifisering med tanke på invasiv undersøkelse med koronar angiografi

Oxford University Press and the authors have approved reprint of table 13 in the original paper. Oxford University Press and the ESC are not responsible or in any way liable for the accuracy of the translation, for any errors, omissions or inaccuracies, or for any consequences arising therefore. Stefan Agewall is solely responsible for the translation published in this publication

\section{RAMME 1}

\section{Klinisk klassifikasjon av brystsmerter}

For klinisk klassifikasjon som typisk angina pectoris må følgende tre kriterier være oppfylt:

- Substernalt ubehag/smerte i brystet av karakteristisk kvalitet og varighet

- Symptomene er utløst av fysisk eller følelsesmessig stress

- Symptomene lettes i løpet av noen minutter ved hvile og/eller nitrater

Ved atypisk angina er to av kriteriene oppfylt. Dersom kun ett av kriteriene er oppfylt, er det sannsynlig at pasienten har ikkeanginøse brystsmerter

bør heller ikke benyttes som screeningtest hos pasienter uten symptomer på koronarsykdom.

\section{Stefan Agewall}

stefan.agewall@medisin.uio.no

Stefan Agewall (f. 1960) er overlege og professor i kardiologi ved Hjertemedisinsk avdeling, Oslo universitetsykehus, Ullevål, og Universitetet i Oslo.

Forfatter har fylt ut ICMJE-skjemaet og oppgir følgende interessekonflikter: Han har mottatt fordragshonorar fra AstraZeneca, BoehringerIngelheim, Pfizer, Medicine Company, Roche, Sanofi og Siemens.

\section{Litteratur}

1. Montalescot G, Sechtem U, Achenbach S et al. 2013 ESC guidelines on the management of stable coronary artery disease: the Task Force on the management of stable coronary artery disease of the European Society of Cardiology. Eur Heart J 2013; 34: 2949-3003.

2. Genders TS, Steyerberg EW, Alkadhi H et al. A clinical prediction rule for the diagnosis of coronary artery disease: validation, updating, and extension. Eur Heart J 2011; 32: 1316-30.

Mottatt 28.11. 2013, første revisjon innsendt 11.12. 2013, godkjent 12.2. 2014. Redaktør: Matilde Risopatron Berg.

Publisert først på nett. 